\title{
One cornea for two patients: case report
}

\author{
Uma córnea para dois pacientes: relato de caso
}

\author{
Ljubisa Nikolic ${ }^{1}$ \\ Vesna Jovanovic ${ }^{2}$ \\ Mirko R. Jankov II ${ }^{3}$
}

Work carried out at Eye Department of Belgrado Municipal Hospital - Serbia.

' Ocular Disease Clinic, Municipal Hospital, Belgrado, Serbia.

${ }^{2}$ Ocular Disease Clinic, Municipal Hospital, Belgrado, Serbia.

${ }^{3}$ LaserFocus, Eye Microsurgery Center, Belgrado, Serbia.

Correspondence address: Ljubisa Nikolic. Dimitrija Tucovica, 161 - 11000 Belgrado, Serbia

E-mail: ljnikolic@yubc.net

Recebido para publicação em 22.02.2009

Última versão recebida em 07.10.2009

Aprovação em 29.11.2009

\begin{abstract}
Case reporting the use of one donor cornea for two transplantation procedures: deep anterior lamellar keratoplasty (DALK) in a case of an imminent corneal perforation caused by herpetic stromal necrosis, and Descemet stripping with endothelial keratoplasty (DSEK) in an eye with pseudophakic bullous keratopathy (PBK). Descemet's membrane (DM), denuded by stromal necrosis, served as the starting point for dissection plane and creation of the recipient bed for DALK. The next steps were excision of the diseased stroma along the edge of trephination, and transplantation of a 400-450 $\mu \mathrm{m}$ thick, manually dissected lamellar graft. The remaining posterior layers of the donor cornea, 100-150 $\mu \mathrm{m}$ thick, were used as a graft in the DSEK procedure for PBK. The integrity of the globe was saved, and best-corrected visual acuity (BCVA) of 20/40 was reached after DALK in the eye with an imminent corneal perforation. A subnormal central corneal thickness (CCT) of $430 \mu \mathrm{m}$ did not interfere with corneal shape $(43.50 \mathrm{x} 45.50 \mathrm{D})$ and function. The graft remained attached and clear after DSEK in the eye with PBK, with BCVA of 20/30 and a CCT of $653 \mu \mathrm{m}$. One donor cornea can be used for two lamellar keratoplasties, DALK and DSEK. Although the described obstacles may prevent this approach from becoming widely used, it may prove useful when one is confronted with a need for an urgent anterior lamellar keratoplasty, a long list of cases for DSEK, and a shortage of donor corneas.
\end{abstract}

Keywords: Corneal transplantation/methods; Tissue donors; Endothelium, corneal/transplantation; Descemet-stripping endothelial keratoplasty; Corneal diseases

\section{INTRODUCTION}

In Descemet stripping with endothelial keratoplasty (DSEK), a folded posterior corneal lamellar disc of the donor is inserted through a small limbal incision and attached by an air bubble to the recipient stromal bed created by stripping Descemet's membrane together with dysfunctional endothelium $^{(1)}$. This technique has gained much popularity as an alternative to penetrating keratoplasty (PK) in the management of corneal endothelial disorders ${ }^{(2)}$.

Deep anterior lamellar keratoplasty (DALK) is another alternative to PK, aimed at saving healthy recipient endothelium in cases of stromal involvement with a functionally intact endothelium. Saving intact Descemet's membrane, while removing all of the recipient stroma, is the most challenging part of this surgical procedure ${ }^{(3)}$.

Corticosteroids are contraindicated with active epithelial herpes simplex virus infections ${ }^{(4)}$. In their presence herpetic corneal melting may ensue and necessitate an urgent keratoplasty in order to save the integrity 
of the globe. However, an extra donor cornea may not be available at that moment. A case when such a situation was resolved by using one donor cornea both for a scheduled DSEK procedure in one patient, and for an urgent DALK in the treatment of an imminent corneal perforation in another patient is reported.

\section{CASE REPORT}

\section{Case 1}

A 60-year-old woman was referred to us, after her painless left eye, with a history of recurrent herpes simplex keratitis, had been treated with $1 \%$ prednisolone drops for ten days. Visual acuity (VA) was light projection. The central $8 \mathrm{~mm}$ corneal portion was opaque, edematous, partially necrotic, and anesthetic, with a paracentral, $4 \times 3 \mathrm{~mm}$ melt down to Descemet's membrane. Her right eye was inconspicuous. The recipient bed was prepared by a central, $7.0 \mathrm{~mm}$, partial thickness corneal trephination and dissection at the level of DM partially denuded by melting (Figure 1A). The dissected stroma was cut off along the trephination mark, and the intact, clear DM was ready to be covered with a lamellar graft.

A whole globe of a 43-year-old donor was used for a manual preparation of two $8.0 \mathrm{~mm}$ corneal grafts: one, intended for DSEK, which included endothelium together with Descemet's membrane and a thin layer of the posterior stroma; and the other, which included most of the donor stroma together with epithelium, for the DALK procedure (Figure 1B). A $5.0 \mathrm{~mm}$ vertical cut with a rounded blade and a stop at $0.5 \mathrm{~mm}$ (BD Pharmaceuticals) was made at the limbus using some pressure to penetrate as close to DM as possible and the

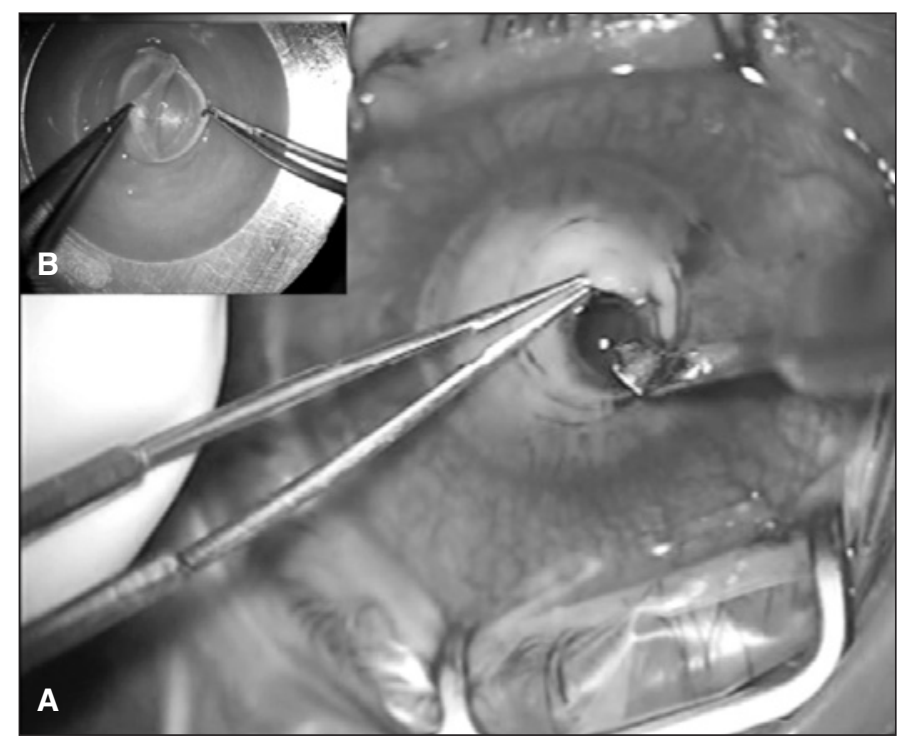

Figure 1 - A) Dissection of the recipient bed at the level of the denuded Descemet's membrane; B) Preparation of two grafts from one donor cornea. The thinner, folded graft is for endothelial transplantation while the thicker one is for deep anterior lamellar keratoplasty. initial stromal cleavage was made with a Paufique knife (Geuder, Heidelberg, Germany), followed by a lamellar dissection from limbus to limbus with a Castroviejo spatula (Geuder, Heidelberg, Germany). After the corneoscleral button had been excised, an $8.0 \mathrm{~mm}$ trephine was used to cut it from the endothelial side. The endothelium was covered with a drop of Amvisc (Bausch and Lomb Pharmaceutical, Berlin, Germany). The grafts were divided, and the thicker graft was put onto the recipient bed, (Figure 2A) and sutured; $0.5 \%$ prednisolone eye drops were given t.i.d. for three months and once daily for another three months. Oral acyclovir at $400 \mathrm{mg}$ five times daily was given for three months, followed by twice daily for another 12 weeks. Ciliary hyperemia was minimal. Neither the aqueous flare nor corneal inflamation were observed.

At the end of a three months follow-up, the central corneal thickness (CCT) was 430 micrometers (Orbscan, Bausch and Lomb, Munich, Germany), and the BCVA was 20/40 (correction -1.00 Dsph x -1.00 Dcyl ax 120). Two years after surgery keratometric values are 43.5 and $45.5 \mathrm{D}$ and BCVA is 20/40 with -2.00 Dcyl ax 110. Biomicroscopy does not show any scar formation at the graft-host interface.

\section{Case 2}

A 76-year-old woman with a PBK of six months duration in her right eye was scheduled for DSEK. That eye had a visual acuity (VA) of hand motion. Her left eye had a $2+$ nuclear sclerotic cataract and a vision of 20/40.

Using the $8 \mathrm{~mm}$ trephination mark as a guide, DM and endothelium were scored and removed with a modified PriceSinskey hook and a Price irrigation stripper (Moria, Antony, France) through a $5 \mathrm{~mm}$ scleral tunnel. The anterior chamber was filled with air. The posterior lamellar graft was folded over, with the endothelial side inward, for insertion into the

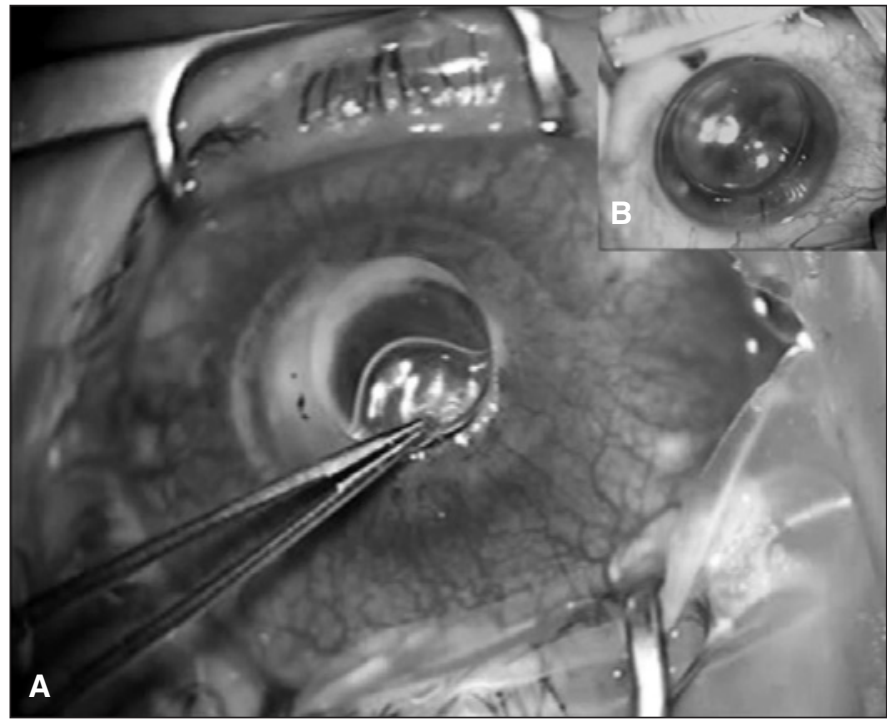

Figure 2 - A) Air bubble compressed between the intact recipient's Descemet membrane and the anterior lamellar graft; B) Posterior lamellar graft in the recipient bed. Anterior chamber filled with air. 
recipient eye. Some extra air was used to unfold the graft and to attach it to the recipient stroma (Figure 2B). The limbal incision was sutured with the interrupted 10-0 nylon sutures. A Lindstrom LASIK roller (BD Medical) was used to move the graft into the central position, as well as to drain additional fluid from the interface through four midperipheral corneal stabs, as described by Price $^{(2)}$.

An intravenous infusion of $100 \mathrm{ml}$ of $20 \%$ manitol was given. The residual air was left in the anterior chamber for two hours when it was replaced by balanced salt solution.

After a three months follow-up, the graft remained attached, CCT was 653 micrometers (Orbscan, Bausch and Lomb, Munich, Germany), and the UCVA of 20/60 was reached. Two years after surgery, BCVA is 20/30 (correction -1.00 Dsph $\mathrm{x}$ -1.25 Dcyl ax 70).

\section{DISCUSSION}

Using both parts of the donor button, at least in some cases, could be a small step towards the solution of an ever present shortage of the donor material. There are, however, obstacles to this approach. It is not easy to match each patient scheduled for DSEK with a patient scheduled for DALK. Further, if the anterior lamellar graft is too thin, a cornea ectasia may ensue.

Neither of these obstacles was present when we decided to perform the described corneal transplantations. We believe that the situation which we present here is not altogether unique, and that a patient with an indication for DSEK can often be recruited at the time when an urgent DALK is needed.

The donor cornea intended for two grafts must be dissected as close to Descemet's membrane as possible ${ }^{(5)}$. CCT after DALK suggests that this happened in the presented cases. The $1.0 \mathrm{~mm}$ discrepancy between the anterior lamellar graft and the host bed is more than the recommended $0.50-0.75 \mathrm{~mm}^{(5)}$ to avoid an excessive suture pull on the corneal tissue that surrounds the necrotic area.

Although certain obstacles prevent the use of one donor cornea for two grafts from becoming widely used, it may prove useful when one is confronted with a need for an urgent anterior lamellar keratoplasty, a long list of cases for DSEK, and a shortage of donor corneas.

\section{RESUMO}

Relato de caso descrevendo o uso de uma córnea doadora para dois procedimentos de transplante: ceratoplastia anterior lamelar profunda (DALK) no caso de uma perfuração corneal iminente causada por necrose estromal por herpes vírus, e ceratoplastia com transplante de endotélio (DSEK) no olho com ceratopatia bolhosa em pseudofacia (PBK). A membrana de Descemet (DM), previamente desnudada pela necrose estromal, serviu como ponto de partida para o plano de dissecção e da criação do leito estromal para DALK. Os passos seguintes foram a excisão do estroma acometido até a borda da trepanação, transplante de um botão doador de aproximadamente $400-450 \mu \mathrm{m}$ de espessura manualmente dissecado. As camadas posteriores restantes da córnea doadora, com a espessura de 100-150 $\mu \mathrm{m}$, foram utilizadas para o procedimento DSEK no olho com PBK. A integridade do globo ocular foi mantida, e a acuidade visual melhor corrigida (BCVA) de 20/40 foi alcançada após DALK no olho com a perfuração corneal iminente. A espessura corneal central (CCT) de $430 \mu \mathrm{m}$ abaixo da normal não interferiu com a curvatura anterior da córnea $(43,50$ x 45,50 D), nem com a sua função. O transplante de endotélio manteve-se tópico e transparente após DSEK no olho com a PBK, com uma BCVA de 20/30 e CCT de $653 \mu \mathrm{m}$. Uma córnea doadora pode ser utilizada para duas ceratoplastias lamelares, DALK e DSEK. Apesar de, devido os obstáculos descritos, pode não ser recomendada para o uso cotidiano, esta abordagem mostra-se útil nos casos da necessidade de uma ceratoplastia lamelar anterior de urgência, a longa lista para DESK e a falta de córneas doadoras.

Descritores: Transplante de córnea/métodos; Doador de tecidos; Endotélio posterior/transplante; Ceratoplastia endotelial com remoção da membrana de Descemet; Doenças da córnea

\section{REFERENCES}

1. Melles GR, Wijdh RH, Nieuwendaal CP. A technique to excise the descemet membrane from a recipient cornea (descemetorhexis). Cornea. 2004;23(3):286-8.

2. Price FW Jr, Price MO. Descemet's stripping with endothelial keratoplasty in 200 eyes: Early challenges and techniques to enhance donor adherence. J Cataract Refract Surg. 2006;32(3):411-8.

3. Anwar M, Teichmann KD. Deep lamellar keratoplasty: surgical techniques for anterior lamellar keratoplasty with and without baring of Descemet's membrane. Cornea. 2002;21(4):374-83.

4. Hoffman CJ, Laibson PR. Corneal manifestations of local and systemic therapies. In: Krachmer JH, Mannis MJ, Holland EJ, editors. Cornea. $2^{\text {nd }}$ ed. Vol. I. Fundamentals, diagnosis and management. Philadelphia: Elsevier Mosby; 2005. p.887-95.

5. Benson WH, Goosey JD. Lamellar keratoplasty. In: Krachmer JH, Mannis MJ, Holland EJ, editors. Cornea. $2^{\text {nd }}$ ed. Vol. II. Surgery of the cornea and conjunctiva. Philadelphia: Elsevier Mosby; 2005. p.1685-93. 